\title{
Patriotism, nationalism and modernity
}

\section{The patriotic societies in the Danish conglomerate state, 1769-1814}

Engelhardt, Juliane

Published in:

Nations and Nationalism

Publication date:

2007

Document version

Early version, also known as pre-print

Citation for published version (APA):

Engelhardt, J. (2007). Patriotism, nationalism and modernity: The patriotic societies in the Danish conglomerate state, 1769-1814. Nations and Nationalism, 13(2), 205-224. http://www.blackwellsynergy.com.ep.fjernadgang.kb.dk/doi/abs/10.1111/j.1469-8129.2007.00278.x 


\title{
Patriotism, nationalism and modernity: the patriotic societies in the Danish conglomerate state, 1769-1814
}

\author{
JULIANE ENGELHARDT \\ Department of History, University of Copenhagen, Denmark
}

\begin{abstract}
This article investigates sixty-three patriotic societies established in the Danish conglomerate state during the Age of Enlightenment, since they can throw light on the pre-national collective identities. It explains how the patriotic societies had both an external function in regard to society and an internal function among their members. It analyses how the members comprehended patriotism and how they propagated ideas of solidarity and good citizenship to a wider audience. The patriotism of the eighteenth century is also compared with the nationalism of the nineteenth century, and the way they reflect two different understandings of core concepts such as state, language and folk culture is explained. However, both ideologies correlate to modernity, since they reflect the same dialectic tension in the relationship between the individual, the social community and the modern state.
\end{abstract}

KEYWORDS: bourgeoisie/middle classes, Denmark-Norway, nationalism, patriotic societies, patriotism, the Enlightenment.

\section{Patriotism at the end of the Enlightenment era}

During the Age of Enlightenment patriotism was one of the dominant concepts in the public debates all over Europe. The first patriotic impulses emanated from Great Britain, where Public Spiritedness was a call to subordinate private interests to the common good. In France, patriotism was also a concept that committed the citizen to the volonté générale. In the French Encyclopaedia, which was published in 1751-72, patriotism was defined as a political virtue, and during the French Revolution around sixty newspapers and periodicals were published in which Patriot or Patriotism was part of the title. In Germany and most other European countries, numerous patriotic societies were established, which all had the same overall objective: to promote the general welfare of the population and the state (Busch and Dierse 1989).

This article investigates the patriotic societies that were established in the Danish conglomerate state in the decades around 1800. They were established by enthusiastic citizens in order to promote patriotism in the population at 
large. Since they thus explicitly explained what patriotism was, the patriotic societies provide excellent material for investigating how patriotism was understood at the time and the attempts made to create a trans-local feeling of solidarity during the rise of the modern state.

According to A. D. Smith's historiography review in Nationalism and Modernism, the vast majority of modern researchers of nationalism date the emergence of modern nationalism to the years of the French Revolution (Smith 1998: 17, 112 and 126). I believe this is partly because patriotism and nationalism are often used as synonymous concepts. An example of this is the three-volume anthology: Patriotism: the Making and Unmaking of British National Identity (Samuel 1989). Here patriotism and national identity are used alternately and without explicitly stating the meaning of the words. Other researchers, such as Linda Colley and Eric Hobsbawn, recognise distinctions as well as overlaps between the concepts (Colley 1996; Hobsbawn 1990). However, there is still need for an analysis of how the two concepts of patriotism and nationalism represented two different understandings of the state, the people and the ethnic culture. The purpose of this article is thus to examine patriotism as a historical concept in its own right and explain how it represented a different kind of collective identity from nationalism.

The most exhaustive account so far of patriotism and how it differed from national identity is given by Maurizio Viroli in For Love of Country: an Essay on Patriotism and Nationalism (1997). Among the Nordic researchers who distinguish between patriotism and nationalism, some co-ordinate patriotism with patriarchalism. Patriotism is described as a loyalty, characteristic of an absolute state, in which the King governed his subjects with paternal care, as opposed to nationalism, which is equated with democratisation. ${ }^{1}$ The question is whether this was really the case. In most European countries patriotism was used in defence of a republican form of state, and the patriotic societies, discussed below, distanced themselves from royalist patriarchalism. This article will demonstrate how, and analyse the ideas and forms of state reflected in patriotism and patriarchalism, respectively.

Why are the patriotic societies interesting in the context of nationalism research?

- One result of the last twenty to twenty-five years' rejection of the traditional understanding of nationalism is an increased interest in pre-national feelings of identity. The patriotic societies are interesting in this context, since they can deepen our understanding of the patriotism of the Enlightenment. Furthermore, by investigating the patriotic societies in Norway, Schleswig and Holstein, i.e. territories that were a part of the Danish state but were not Danish in the national meaning of the word, we can analyse whether the patriotic feeling of community spanned different nationalities.

- The societies are also interesting because the members were recruited predominantly among the middle class, and the societies played a significant role in establishing the middle class as an influential group within 
the state and creating a bourgeois identity. The patriotic societies thus constituted an important element in what has been termed the bourgeois public sphere.

- Finally, the societies are interesting because they reflected essential ideas of the Enlightenment: economic liberalisation, the development of public welfare institutions, individualism, emancipation and discipline.

The analytical approach in this article is sociological, since it deals with the patriotic societies as a historical and cultural phenomenon, and not with their specific history. I will depict the social forces that shaped and promoted the patriotic ideas and show how the establishment of the societies reflected changes in the social structures during the period. An analysis of these can explain why the patriotic societies were established and why patriotism, which had been a well-known concept since classical Antiquity, gained such wide dissemination in the Age of Enlightenment. The method is also phenomenological, as I will explain how the members comprehended patriotism and presented it to a wider audience and to what extent the societies constituted a shared frame of reference. Their understanding of patriotism will be compared with the ideas of national romanticism, and the roles of the state and the people envisaged in the patriotic and the national ideologies will be explained.

\section{The patriotic societies}

In the eighteenth century the Danish conglomerate state included a much larger area than the present Danish state and consisted of several different cultures and languages; Norway and Denmark were united under the Danish King in 1380, and Norway brought the crown colonies of Iceland, the Faroe Islands and Greenland into the union. The realm also included the two duchies of Schleswig and Holstein. ${ }^{2}$ The form of government in the state was absolute monarchy. This was introduced in 1660, but the landed gentry in Denmark, Schleswig and Holstein still held considerable power during most of the eighteenth century. Each estate was an area with its own jurisdiction and the landowners were responsible for elementary schooling and for poor relief on their estates. This meant that legal decisions and the provision of social welfare in the state taken as a whole were arbitrary. The power of the landowners began to be dismantled only at the end of the eighteenth century, as the state extended its administrative and social welfare institutions to local communities and land was being sold to small farmers. The middle class was also growing. This was due both to the growth of public administration and the recurrent wars between the great sea powers in Europe, during which Danish ships sailed under the neutral Danish flag. This meant a rise in the number of government officials and increased income for the merchants and traders.

In this multinational conglomerate state, sixty-three patriotic societies were established between 1769 and 1814: thirty-eight in Denmark, nineteen in 
Norway and six in Schleswig and Holstein. Most of them were established in the university cities of Copenhagen, Kiel and Kristiania (today: Oslo), but there were also many in the market towns and in remote parishes all over the realm. The first society, and the only one that worked nationwide, was the Royal Society of Agriculture (Det kongelige danske Landhusholdningsselskab). This was clearly inspired by the Royal Society for the Encouragement of Arts, Manufactures and Commerce, founded in London in 1754. Most of the other societies were named after the town or area in which they were established: The Society for Promoting Enlightenment and Industry in Lolland-Falster County (Selskabet til Oplysningens og Industriens Fremme i Lolland-Falster Stift), Die Gesellschaft freiwilliger Armenfreunde zu Kiel and Die schleswigholsteinische patriotische Gesellschaft are examples of these. Others were simply named after the society's main mission, such as the Society for Civic Virtue (Selskabet for Borgerdyd) and the Sisterly Charity Society (Det søsterlige Velgørenhedsselskab). ${ }^{3}$ The largest societies were situated in Copenhagen and had 400-500 members, some even more than 1,000. The societies in the provinces typically had $50-100$ members.

The establishment of patriotic societies was not just a Danish phenomenon; patriotic societies came into being all over Europe during the eighteenth century, and so far 233 have been mapped (they are listed in van Dülmen 1986: 152-5; im Hof 1982: 259-63; Müller 1975: 277-86). The patriotic societies in the Danish state were very similar to the societies in Great Britain and Germany, in terms of both goals and organisational structure (Bödeker 1999; Clark 2001). There was no formalised cooperation between the societies; they were all independently organised and established as local enterprises. But the founders of the societies in the Danish state clearly used thoughts and ideals from abroad and applied them to domestic conditions. They emphasised that they regarded their societies as part of a larger European movement, and made no attempt to hide the fact that they borrowed extensively from the foreign societies in drawing up their rules and regulations.

In contrast to the numerous salons, coffeehouses, learned societies, Masonic lodges, Jacobin Clubs and reading societies, which were also a significant feature of the eighteenth century, the members of the patriotic societies emphasised the importance of translating enlightened ideas into practical work for the peasant population. The members thus carried out many activities in order to implement social, industrial and educational reforms in the cities and provinces of the realm. They distributed pamphlets among the peasants about new crops and methods of cultivation, they reorganised health care and poor relief in several towns and they established institutions for the purpose of enlightening the peasant population. The patriotic societies were also forums for political debate among the members. These were published in pamphlets so that everyone could keep up to date about points of view on the state, absolute rule and the need for reforms, which were expressed in the societies. Although the patriotic societies organised activities in different areas, their unifying objective was to promote 
the welfare of the fatherland, 'the common good', and patriotic feelings among the population. The members continually stressed the fact that they acted out of love for country, that the establishment of the patriotic societies expressed their commitment to the common welfare, and that they felt obliged to help their fellow citizens and support the state.

Who joined the patriotic societies, and what social strata were the recruiting grounds? The majority of the members belonged to the bourgeoisie. However, the term must be understood in a broad social and geographic meaning. It comprised both ministers of state and merchants in the bigger cities, as well as university-trained state officials and tradesmen in provincial towns and rural areas. However, in the patriotic societies, the members behaved as a unity and endorsed the same bourgeois attitudes and values. The societies reflected a process during which the meaning of the term bourgeoisie changed. Bourgeoisie had previously been a category of estate, which designated master craftsmen and retailers in the market towns, who were protected by formal estate rights and guild rules. In the course of the eighteenth century the formal criteria disappeared. The term bourgeoisie increasingly became a social distinction, a community based on a shared lifestyle and values, in which the informal indicators of belonging were being cultured and of decent behaviour.

In spite of differences in rank and social status, all members were considered to be of the same standing within the societies; every member had the same right to participate in debates, all decisions were made after ballots based on the principle of one man, one vote, and on the societies' lists of members everyone was listed in alphabetical order. In this way, the rank and estate hierarchy, which existed outside the societies, was suspended within them. The significance of this democratic way of organising the societies should not be underestimated; it both increased the feeling of solidarity among the members and meant that the societies functioned as forums in which the members could debate on an equal footing, which was not possible in traditional society. Thus the patriotic societies became miniature experiments of a parliamentary state.

Why did the patriotic societies arise at all, and why in the late Enlightenment in particular? Earlier in the 18th century patriotism was considered to be a matter for university professors and learned people. The establishment and the geographic dispersal of the societies in the second half of the century reflected the fact that patriotic ideas had by then reached wider circles in the population. This also marked a shift in the understanding of who was considered to be important in bringing about progress and welfare in the state. The societies were established with the explicit object of making the rays of 'the Enlightenment's Sun' reach every single citizen in every part of the realm. The members emphasised that every person played a role in terms of contributing to the general welfare, and they saw themselves as spearheads of the Enlightenment, which brought the joys of civilisation to every person in every remote corner of the state. In the eyes of the members, patriotism and 
enlightenment were two sides of the same coin; in order to become a good patriot one had to be enlightened and vice versa.

There were also more tangible political conditions in the Danish conglomerate state that profoundly influenced the goals of the patriotic societies. Crown Prince Frederic - from 1808 King Frederic VI - assumed power in 1784, since his father, the Absolute Monarch King Christian VII, was schizophrenic. The Crown Prince implemented reforms according to which the state took over and extended important parts of the social and legal institutions, which had previously been under the jurisdiction of the estates. Thus, the state increasingly became a dynamic power in the towns and local communities. Parallel with this development an ideological rearmament took place. Restrictions on the press were eased in the period 1784-99, and periodicals and pamphlets gave voice to public opinion with a lively engagement in governmental and social affairs. The bourgeoisie made up the great majority of the participants in the public debates. A prevailing demand was the need for improvements and reforms, and reformism was generally linked to patriotism and a demand for a more interventionist state. In this situation patriotism was used as an integrating concept to create a feeling of commitment to the state among the citizens, as the former expanded its position of power.

\section{The idea of patriotism}

How was patriotism understood by the members and how did they present it to the public? Patriotism was an ambiguous concept with several connotations, and three overriding meanings can be singled out, concerned with economics, education and the defence of civil rights.

In economic terms, patriotism meant protecting domestic trade and industry by minimising imports. The members argued that not only should the state maintain high duties on imported goods, but that inhabitants should also show economic responsibility by preferably buying domestic goods and minimising the consumption of luxury products. Furthermore, members of the patriotic societies aimed to increase productivity in all professions and make the state self-supporting as far as possible. No element was considered too big or too small with regard to the overriding goal of promoting the economic progress of the country; it was characterised as patriotic to cultivate flax, hemp and potatoes, to weave linen, to set up beehives, produce soap from fish, bread from bone meal, to skin dead animals, to use peat as fuel and many other things.

The members of the patriotic societies did not subscribe to any economic theory, but elements of different theoretical sources can be traced. Their protectionist understanding of the international exchange of goods was in line with traditional mercantile policy and the basic assumption that it was possible to generate economic growth by being thrifty and minimising 
consumption. It was a defensive economic belief rooted in the pre-industrial idea that the sum of the world's goods was constant and economies relatively static. However, the members were also influenced by liberal ideas. They opposed subsidisation of industry by the state, and they also considered the mobilisation of enterprising forces in the population at large as a precondition for economic growth. The notion that the economy could be expansive and cumulative was beginning to gain ground, which can also be observed in the members' use of buzz words such as invention, progress, improvements and change. The members were also inspired by cameralism, according to which the state should not interfere directly with economic life, but create the necessary preconditions for a dynamic economy by providing a labour force which was both numerous and healthy, and which had a relatively high level of education.

The second understanding of patriotism was education of the lower orders. The starting point in the patriotic societies' debates was that the peasants were lazy, contrary and narrow-minded. This was a rather harsh verdict, but they also raised the question of why the peasants should be any different. The problems were not rooted in the nature of the peasants, but in their social situation, and they could thus become enlightened and industrious provided that the necessary resources were procured. This generated a dynamic spirit and the patriotic societies enthusiastically endeavoured to mobilise the means necessary. They established elementary schools and peasant libraries, they held reading circles and distributed publications aimed at increasing productivity and improving the morals of the peasants. Their educational efforts were distinctively utilitarian in that the peasants were seen as an unexploited source of economic growth, and education as a remedy to increase their productivity. In addition, the members believed that enlightenment prevented riots and social disturbances, since it would give the people a better understanding of why it was necessary to comply with the law. In short, enlightened citizens would be both industrious and law-abiding. In order to realise this growth potential, the peasants were stimulated to be hard-working, selfmotivating and to make profitable use of time, as an industrious culture was seen as a prerequisite for economic growth. The societies rewarded hardworking villagers with prizes, and the prizes were regarded as an effective means to overcome peasants' laziness and aversion to change, which the members considered to be the main impediment to the implementation of reforms. The call to an industrious way of life was about internalising a new work ethos so that each individual felt an inner urge to be diligent and acted in a way that was characterised by discipline and self-restraint. In this way the societies were a condensation of the civilising process as described by Norbert Elias. Their ideas are also in accordance with Max Weber's explanation that capitalism is just as much a cultural and social-psychological matter as an accumulation of pounds and shillings (Elias 1997; Weber 1993). Or, to put it in another way, the individual should not only be industrious, he should also want to be industrious. However, it would be a simplification to reduce the 
patriots' efforts to a question solely of maximising the utility of the peasants. Their wish to raise the general level of education also stemmed from social indignation. The patriots reasoned that enlightenment made people mild and generated social empathy, whereas ignorance generated cynicism and violence. They considered it to be beneath the dignity of a human being to be unable to acquire literary knowledge. Everybody had the right to learn to read and write, and to be allowed to read the books they preferred.

This is connected to the third understanding of patriotism, which related closely to civil rights. It was a standing credo among bourgeois public opinion all over Europe that patriotism could only gain ground if the inhabitants could speak, think and write freely (Prignitz 1981: 4-5, 23). It was claimed that the inhabitants would neither feel responsibility to society nor loyalty towards the fatherland unless their basic natural rights as individuals were respected. The primary demands among the patriotic societies in the Danish state were freedom of speech, freedom of movement, guarantee for the title of property and a predictable - as opposed to arbitrary - administration of justice. The members maintained that it was a human right for every citizen to have a sphere that was inviolable and protected against the state. These ideas were closely related to the natural law theories of John Locke. However, the members differed from John Locke in what they believed should be the extent of the state. Locke had argued that the power of the state should be as limited as possible and that its main task was to maintain law and order, in order to give the inhabitants the best opportunities to seek their own goals and desires (Malnes and Midgaard 1993: 124). In contrast to this, the predominant attitude in Denmark was that the state should actively endeavour to improve the welfare of the citizens. General education and healthcare should be provided through an expansion of the public institutions. Although the patriotic societies were actively involved in improving the welfare and educational institutions on a local level, the members still maintained that the state should undertake the overall responsibility for the basic welfare of the inhabitants. Thus, the civil rights championed by the patriotic societies in the Danish state implied both an interventionist state and a containment of the power of the state. The members wanted both more state and less state; to them civil rights meant protection both by the state and against the state. Human beings had rights that existed before the state, and also rights that presupposed a state with a broad net of welfare institutions. This belief in a strong state and the state's responsibility for the happiness of the citizens foreshadows the modern welfare states in Scandinavia and Germany.

\section{The good patriot and the fatherland}

The patriots not only maintained that the state should take responsibility for the citizens' health and happiness, they also endeavoured to mobilise the citizens' engagement with the state. How could a citizen become a good 
patriot? Two concepts were essential: civic virtue, and deeds for the fatherland. The citizen should have the proper disposition and also be minded to use his or her abilities for the state. Citizenship gave an obligation to commitment and enthusiasm, and patriotism was contrasted to apathy and selfishness. Thus patriotism was understood as an activity; one could not be passive. The citizens' love of country could only unfold if they could bring their influence to bear, and the government should thus allow them to be actively engaged in affairs of state.

Since the patriotic societies advocated love of fatherland the question follows, what was the fatherland? Was it the multicultural state, the country, or the region in which each society was domiciled? When the members spoke of the fatherland they mostly referred to the conglomerate state as a whole. They regarded their region or country - Denmark, Norway, Schleswig and Holstein - as territories with their own distinctive culture, history and natural environment, but not as countries taking the place of the conglomerate state. What is important in this context is that the members did not see any conflict between political unity and cultural diversity. This is exemplified by the inhabitants of Schleswig-Holstein often speaking of themselves in German as Dänen, i.e. as Danes. This certainly does not mean that all was harmony. Norway and Denmark had been in a union since the Late Middle Ages, but the understanding of Norway as an independent country never disappeared. In the Norwegian patriotic societies, especially the Society for the Welfare of Norway (Selskabet til Norges Vel), the members expressed deep discontent with the fact that the government would not allow the country a Norwegian university, a Norwegian bank and Norwegian administrative institutions. ${ }^{4}$ Still, this criticism was political in character, and was due to a real imbalance in the union between the two countries.

In the public debates outside the societies, national identities were evolving (Storsveen 1997). Danish identity was almost exclusively expressed as antiGerman sentiments, which became evident in a fierce war of words between the Danish and German subjects. The situation was that about one-third of the population living in Copenhagen was German-speaking, and the most prestigious and politically influential groups in the capital belonged to the German community. This laid the basis for strong anti-German sentiments among the ascending and increasingly self-aware Danish middle class. In 1776 the government introduced a law that reserved positions in the King's service for citizens of the Danish state. This did not exclude the subjects from Schleswig and Holstein, but it clearly met the wishes of the Danish middle classes for a demonstratively Danish policy and for elevating the status of Danish language and culture. In 1789 their aversion to the Germans broke out more fiercely than had been seen before; in periodicals Danes criticised those who 'eat the Bread of the Land' but did not care to learn the Danish language, and they blamed the German elite for being arrogant. The dispute contained elements of both professional jealousy and a feeling of inferiority among the Danes. In the nineteenth century the Danish government strove more 
aggressively to incorporate the two German duchies into the monarchy. There had previously been a low level of integration, but in 1806 Holstein was incorporated into the Danish monarchy and Danish was introduced as the official administrative language in Schleswig, despite the fact that two-thirds of the population were native German speakers. The incorporation of Holstein was never fully implemented and it only became a part of the newly established German Federation in 1815. A new feud arose as the demand in the duchies for Schleswig to follow Holstein into the Federation grew, and this conflicted with the Danish helstatspolitik, i.e. attempts to integrate Schleswig into Denmark. Civil war broke out in 1848, but ended with the status quo. Following a short war in 1864, Denmark was forced by Prussia and Austria to give up the duchy. The conflict was resolved in 1920 when a referendum decided that the northern Danish-speaking part of Schleswig should be included in Denmark and the southern German-speaking part be included in Germany (Brincker 2003; Winge and Feldbæk 1991; Lind 2005).

\section{Patriotism and national identity}

The anti-German sentiments of the last decades of the eighteenth century deeply influenced the notions of 'We' and 'Them' in Denmark in the nineteenth and twentieth centuries. Ironically, Denmark and Germany were part of the same cultural sphere, and national romanticism - or the organic version of nationalism - put into words by J. G. Herder swiftly gained a foothold in Denmark. This was further elaborated by the Danish writer N. F. S. Grundtvig, and disseminated through the numerous folk high schools that were founded from the middle of the nineteenth century onwards in order to make the people aware of - today we would say construct - their specific Danish national character.

Still, the budding nationalism of the eighteenth century did not find its way into the patriotic societies. Their understanding of patriotism was basically non-national since they regarded patriotism as a universal set of ideas which applied to man as such. They argued for a stronger state, but this was not in support of the nation, nor was their goal a nation-state. They saw the state as a bureaucratic organisation and its welfare institutions as local solutions to universal problems. The following is a phenomenological analysis of the patriotism propagated by the patriotic societies, and of the organic nationalism that became very widespread in Denmark in the nineteenth century.

In the patriotic societies, love of country was not thought to be an innate feeling but rather an attitude one could learn through enlightenment and education. Their concept of an enemy was not other nationalities, but what were termed false patriots or anti-patriots. What did these terms mean? They designated people who were selfish and blasé, and were contrasted with people who had the will to work for the state and their fellow citizens. Such concepts as mother tongue, descent and national character were never mentioned and 
did not determine whether a citizen was considered a good patriot. In principle everybody could become a patriot, so long as the person in question had the right attitude. In this basic assumption patriotism differed fundamentally from the national romantic ideas. Here nationality is believed to be a natural part of a person's identity, as revealed in both material culture (clothes, food and national symbols) and in the character and behaviour of the individual. In the nationalist self-image nationalism is not an ism or an ideology, but a basic condition for human existence. Thus the human being cannot acquire or disclaim his national character; the nationality of the individual is perceived as inevitable, fixed and determined from the moment of birth. Patriotism, on the other hand, was related to a person's conscious actions and set of ethical ideas. Patriotism was principally normative and reformatory; the members of the patriotic societies wanted to create among the people a feeling of belonging to the state, and as they saw it they created something new. The nationalist movement was far more descriptive, and maintained that the national character had existed since time immemorial. It could fall into slumber from time to time, but throughout the history of the nation it was always latent in the population and only had to be roused again. The protagonists of the nationalist movement maintained that with the creation of the nation-state the original destiny of man came into being. The patriots referred to the citizens as members of the state, and the state was termed an association. These terms reflect a contractual comprehension of the state; it was seen as a community based on shared opinions, which the citizens had joined voluntarily and which in principle everyone could join or resign from. In contrast to this, national romanticism emphasised the descent of the people; nationality was perceived as one of man's basic characteristics permanent and unalterable - and thus had components of essentialism.

Another distinctive difference between patriotism and nationalism was their respective perceptions of the people: whereas the patriots described the peasants in a matter-of-fact tone as superstitious and lazy, they were viewed in an idyllic light by the national romantics. In the national scheme of things the nobility were regarded as cosmopolitans who spoke foreign languages and were influenced by other cultures. They thus represented a non-national culture. The nobility were contrasted with the peasants, who had lived on and cultivated the soil through generations. Their mentality was believed to have been influenced by the landscape, history and language, and this had created a characteristic culture. In the nationalist chain of reasoning, it was among the peasants - among the people - that one would find the heart and soul of the nation, the national character. The peasants' traditions, beliefs and tales, their mother tongue, food and clothes were believed to reflect a cultural continuity from antiquity to the present day and were thereby manifestations of the national character (Herder 1989: 7th book, chapter 2, 9th book, chapter 1). During the nineteenth and twentieth centuries this material nationality was thus collected, written down and exhibited in museums in order to find and protect the specific national character of the Danes, Germans, Norwegians, 
Swedes, etc. The distinction can be put more sharply, since the patriots saw it as their mission to drag the peasants out of the mire they considered them to be in, while seen through the spectacles of national romanticism, the peasant culture should be preserved.

The non-national character of patriotism raises the question of whether the societies had a concept of an enemy. They certainly had, and despite their claims of universality, there are also examples of cultural narrow-mindedness in their writings. An example of this is their view of non-Christian cultures, as expressed in the anti-slave debate. The situation was that Denmark was one of the leading slave-trading countries in Europe, but, as was the case in Great Britain, public opinion turned against this when the brutality of the trade in slavery became known to the public. The most salient points of criticism were not only the physical violence, but also the fact that the slave owners did not try to convert the Africans to Christianity; the height of inhumanity was that they were allowed to remain as Muslims, that is, as Barbarians (Borgervennen [The Citizen's Friend] 1792).

A closer and more dominant aversion was to the nobility as a class and to aristocratic culture in general. The patriots characterised the nobility as superficial, unrestrained and depraved, and aristocratic culture as a world of concerts, comedies and balls. In contrast to the decadence of the nobility, the patriots pictured themselves as decent, disciplined and, especially, possessors of civic virtue. Whereas the nobility led secluded lives in their castles and estates and lacked engagement with the social problems in the state, the bourgeoisie were actively committed to the welfare of the fatherland and their fellow citizens.

Man is only decent and venerable when he uses his talents and efforts to improve himself and society. Can there be honour without noble birth, without power, without wealth? Yes my friends, unquestionably! The Enlightened citizen discovers the depravities hidden behind the delusions, he tears down the vices from the throne. Neatness and justice, performance of duties, virtues and decent manners; this decides the value of man, this decides his rank and civic virtue! (Selskabet for Borgerdyd [The Society for Civic Virtue] 1785: 7-8).

Paradoxically, the sharp fulminations against the nobility contrast with the fact that several members of the patriotic societies were noblemen, aristocrats or members of the royal family. The relationship between the bourgeoisie and nobility was more balanced than appears from the writings of the societies. Apparently the members did not consider it controversial or problematic to make anti-nobility speeches with members of the nobility in the audience. This raises the question of whether the nobility could be good patriots. They could, provided that they behaved with a genuine civic attitude and did not expect to be honoured automatically or because of their birth or rank. An example of this is a speech delivered at the Royal Society of Agriculture upon the death of the Foreign Minister, Count J. H. E. Bernstorff. The speaker pointed out that it was not Bernstorff's title, but his deeds and personal qualifications, which made him honourable; 'Virtue and Competence determine the true, the only 
real Nobility' (Hübner 1772: 23). Likewise the royal family was celebrated in the societies, but the ovations stressed that it was not because of its inherited position, but because it conducted a modest, disciplined lifestyle, and that its nuclear family life served as a model for the rest of the population: 'We do not bestow an honour on them because by a lucky destiny they have obtained purple robes, coat-of-arms, chivalry and other of the state's titles of honour, but because, through honesty and noble deeds they deserve these and lend lustre to humanity' (Selskabet for Borgerdyd [The Society for Civic Virtue] 1785: 18).

The patriotic societies were not opposed to some people being ennobled. But they criticised the nobility's prerogatives and especially the fact that nobility was hereditary, since in that way somebody obtained something for which they had not worked hard. The societies championed meritocracy, according to which an individual valuation of education and skills should give access to top positions in the central administration. Not surprisingly, they maintained that it was 'the Class of enlightened, of educated, of decent Citizens' who should be honoured, as opposed to the old social order, which rewarded flattery and inherited rank (Selskabet for Borgerdyd [The Society for Civic Virtue] 1785: 17). The participation of the nobility was not only characteristic of the patriotic societies in the Danish state; investigations of the patriotic societies in Sweden, Germany and Great Britain show that here too the nobility was actively engaged (Christensson 1996: 159-69; Colley 1996: 91-105). This indicates that the nobility's understanding of its own position in the state was beginning to change, and that it wished to be open to the social and cultural changes in the period. Thus the traditional high status groups began to take over the norms of the middle class.

The peasant population, however, although being the object of the societies' reform activities, never participated in the societies and in most cases they were not invited to join. Only one society actually asked the local peasant population to become members, but the invitation was not accepted. Despite the patriots' call for solidarity and good citizenship, the lower and middle-upper classes still entertained a deeply rooted suspicion of each other and a lack of willingness to enjoy each other's company.

\section{Political goals}

The patriots based their concept of an enemy on social rather than national stereotypes. They created a distorted picture of the upper and lower classes in society, describing the peasantry as ignorant and the nobility as a group who only had eyes for luxury and amusements. This caricatured description of 'The Others' was part of the members' creation of a group identity as the bourgeoisie. Furthermore, it was a rejection of a society in which the political and cultural influence of the nobility was still dominant, and the bourgeoisie's countermeasure was to castigate the nobility as morally suspicious. 
This raises the question: what were the patriotic societies' long-term political ambitions, and did they have a clear political goal? In most other European countries, especially in politically leading countries such as Great Britain, France and the Netherlands, the term patriots designated groups who were in opposition to absolute monarchies and who championed political ideas that were radical at the time (Cunningham in Samuel 1989: 58-89). The patriotic societies were furthermore faced with a European intellectual tradition, according to which love of country was equated with love of the republic. This tradition went back to classical antiquity and was revived incisively by Montesquieu and Rousseau (Viroli 1997: chs 1 and 3). In the Danish State, the members' understanding of patriotism was in line with this European tradition in that they equated patriotism with political freedom. However, this put them in a dilemma; could patriotism exist in a state which had an absolute form of government? The members deftly manoeuvred around this question by distinguishing between the formal form of government and the practical ruling of the state. They attached decisive importance to the latter, and claimed that the form of government was secondary as long as the state was ruled with respect for justice and civil rights. The patriots did not link love of country exclusively to a republican form of state, but maintained that patriotism could exist in an absolute monarchy, provided the citizens were free and enjoyed civil rights. But what about political rights? At no point did the members consider democracy, in the modern sense of the word, as an option; the lower orders should be ensured legal and social rights, but whether they were to be given political rights was not even a theme for discussion. There is no doubt that the members wished to obtain formal political representation for themselves. This was never said or written directly, but it is clearly reflected in the democratic structure of the societies, and in the way that the members here became trained in parliamentary debate. The patriotic societies thus had an important function among the members, as these were a preparation - or, in the words of Jürgen Habermas, a field of practice - for their participation in official political life (Habermas 1990: 88). In the writings of the societies, the members made analogies between 'the small society', i.e. a patriotic society, and 'the large society', i.e. the state. And everybody knew that the organisational structure of the societies, their bourgeois values and ideals, was thought of as a model to be followed in the future organisation of the state. Still, the members never said directly that they wished for constitutional changes and political power for themselves. The most obvious reason for this was that outspoken protests were restricted. There was always a risk of being censored, and censorship did not cease until the introduction of a free constitution in 1849. Furthermore, most of the societies were granted considerable financial support from the royal family and their outgoing activities depended to a large extent on these subsidies. A third reason was that political changes could lead to social riots, or even revolution. This fear was constantly aired in the debates among the members, and it moderated their opinion as to when, how and at what speed the reforms 
should be carried out. They were clearly afraid of losing their grip on things, fearing that swift changes would destabilise society and pave the way for a revolt of the masses. They spoke of rational freedom and civilised freedom, and it is telling that the antonyms of freedom were not only despotism, but also anarchy. The members were politically pragmatic as they believed that it was better to make compromises with the government than to be overrun by 'the unenlightened'. This fear was reinforced during the French Revolution. The patriots in the Danish state at first regarded the events with sympathy, but as the French regime degenerated into a reign of terror they held up the revolution as an example of how badly things could go when political reforms are carried through too quickly.

Although the members were loyal to the absolute monarchy, they still indirectly challenged the legitimacy of this form of state. Patriotism was depicted by the absolute monarchy as being synonymous with love for the King, and the King's semi-official name was father of the country; Pater Patriae. This patriarchal perception of the King was widespread and deeply rooted in most of the population, especially among the lower orders, since they saw him as their protector against the landed proprietor. The patriotic societies implicitly went against this presentation, by singling out patriotism as a concept in its own right, in which the state and the public welfare institutions were the points of reference. In the royal understanding of patriotism, the King as a person was the pivot. In this way the patriots established a distinction between the state and the absolute monarchy. The patriarchal presentation of the King as a father figure was full of emotional overtones, and the relationship between the King and his subjects was presented as the personal relationship between a father and his children, given by nature, eternal and genetic. In contrast to this, the patriots perceived the absolute monarchy as historically contingent and contractual. They made it very clear that the absolute monarchy was legitimate only as long as the King complied with their expectations. In this way they not only distinguished between the king and the state, but also between patriotism and patriarchalism.

\section{Patriotism and modernity}

In the previous sections, the establishment of the patriotic societies is explained by two socio-cultural phenomena: first, the rise of the middle class and its wish to obtain political influence; second, a development during which the state took charge of matters that had previously been affiliated to the villages or the estates. Seen in a larger perspective, the popularity of patriotism was also rooted in more fundamental structural changes, for which the explanations mentioned above are not adequate.

During the Age of Enlightenment the constitutive elements of modernity unfolded: bureaucratic states, urbanisation, public mass education, free and 
public debates and a liberal economic life. To this must be added matters related to cultural history and codes of behaviour, such as individualism, rationality, secularisation, self-restraint and consciousness of time. The patriotic societies encapsulated the process of modernisation in several areas, and in particular individualisation can be seen as an important reason why patriotism had such a great impact. This individualisation was reflected in economic liberalisation, the increasing number of owner-occupiers, and the dissolution of joint cultivation of the soil. Individualisation was also reflected in the ideals of enlightenment and education. One of the goals of education was to dissociate the individual from the belief that there were authorities, such as the church and the government, which had a monopoly of deciding what was true or false, right or wrong. The individual was perceived as authoritative, as the starting point for truth and cognition. Enlightenment was not seen as information about a specific truth, but as enabling the individual to find her own attitudes and values. Finally, the Declaration of Human Rights also promoted individualism, since it adopted the doctrine that the rights of each individual should be ensured. This raises the question: when the individual is perceived as economically, ethically and legally autonomous, how can a feeling of solidarity and community among the individuals be established? How is the individual's commitment to public affairs ensured, and is it possible to make a synthesis of private and public interests, of individual needs and social considerations? (Seligman 1995) In the eighteenth century the citizen's obligation to commit himself to the general welfare of the state was emphasised through patriotism. The patriotic societies were exponents of the dialectic currents of the era, in that they promoted individualism in the above mentioned areas, but they also maintained that individualism without consideration for the common good would undermine society. The societies initiated a conflict with the traditional authorities, but at the same time fear of a moral decline ran as a constant undertone in their publications. Civic virtue was the pivot of their writings, and this can be seen as a moral rearmament in an era in which the existing paradigms for the social order were undergoing rapid transformation. Patriotism was also an integrating response to the departure from the traditional and locally based communities. There was a higher degree of mobility and an explosive increase in the number of written media. Patriotism thus conceptualised a need for a translocal feeling of community. Seen in this perspective it pointed towards national identity.

\section{Concluding remarks}

This article has explained that there were two competing identities in the Danish state at the end of the Enlightenment area: the patriotic identity and the budding national identity. It has also explained how the national sentiments of the Enlightenment were underpinned by romanticism and 
developed into an organic version of nationalism, which became widespread in Germany and the Scandinavian countries in the nineteenth century. This romantic nationalism differed in core areas from the patriotism of the eighteenth century.

Most of the patriotic societies quietly ceased after 1814. Those that continued were de-ideologised and concentrated on - literally - downto-earth subjects; they exist today as agricultural societies. Why did most of the societies give up their enterprise? The reason they themselves gave was that they found it too difficult to implement practical reforms, since the peasant population was too conservative. A more probable explanation is that the patriots' emphasis on utility, good deeds and especially their moralism, became too altmodisch and obsolete in the nineteenth century (Christensson 1996: 376). Still, the basic ideas in patriotism, the emphasis on civil rights and the individual's obligation to show consideration for the common good, did not disappear. They were incorporated into nationalism and are still considered fundamental in modern Western states.

The question of why practically oriented patriotism was replaced by the more introvert national romanticism still remains to be answered. One suggestion is that the patriotic understanding of states as purely bureaucratic organisations failed to appeal to people's deeper emotions. But as Jakob Christensson has pointed out, the appeal of citizenship was not dry rationalism; it could be highly emotional, sometimes even sentimental (Christensson 1996). However, I still believe that national romanticism appealed more profoundly by obliging a personal attachment to the state as it created a totality of the nation's language, landscape, history and national character. Whereas the patriots saw civic virtue as an attitude one could learn, and considered the sheer willingness to participate as crucial, nationalism considered national character to be an innate part of the personality, which determines how the individual thinks and behaves. It thus contained elements of holism, as the individual finds her identity in being a part of the nation, and constitutes herself through the collective. In other words, one could become a patriot, but one is Danish, Norwegian, German, Swedish, etc. This understanding that you are your nationality created an identity both at a personal level and as belonging to the nation. In the middle of the nineteenth century the Danish philosopher Søren Kierkegaard stated that the reverse side of the emancipation that characterises the Age of Modernity is angst. As the individual becomes aware of the fact that he is basically free and therefore responsible for finding his own personal truth, this leads to existential angst. The idea embedded in national romanticism, that the national character is part of the essence of the human being, and that one thus has it of necessity, and that it is absolute and eternal, can be seen as a response to this anxiety and uneasiness. It gives a feeling of continuity and ontological security in a modern changing world. 


\section{Notes}

1 Löfgren 1989: 7;' The wider concept of patriotism is based upon the love of God, King and Country by subjects of the State, whereas the idea of nationalism is based upon ideas about "Volksgemeinschaft", a shared history and culture, an idea of equality and fellowship.'; Damsholt 2000: 112-13.

2 The Danish monarch was the ruler of the countries until the peace agreement in Kiel in 1814. The result of this was that Norway entered into union with Sweden, whereas the overseas possessions remained under Danish control. Norway was granted national independence in 1905. As Duke of Holstein, the Danish King had a seat in the German Reichstag and was a vassal under the German Emperor.

3 A complete list of the sixty-three societies is published in J. Engelhardt 2007.

4 Norway was granted a university in 1811. Another point of criticism was that Denmark had retained the exclusive right to sell corn to the southern parts of the country until 1788 . Since the Danish farmers were not always able to supply the corn that was needed, famine sometimes occurred in some parts of Norway.

\section{References}

Borgervennen [The Citizen's Friend]. 1792. No. 19. Copenhagen.

Brincker, Benedikte. 2003. 'A "small great national state": an analysis of the cultural and political factors that shaped Danish nationalism, 1760-1870', Journal of Historical Sociology 16, 4: 407-31.

Busch, H. J. and Dierse, U. 1989. 'Patriotismus', in J. Ritter and K. Gründer (eds.), Historisches Wörterbuch der Philosophie. Basel: Schwabe \& Co AG Verlag.

Bödeker, H. E. 1999. 'Medien der patriotischen Gesellschaften', in Ernst Fischer, Wilhelm Haefs and York-Gothart Mix (eds.), Von Almanach bis Zeitung. Ein Handbuch der Medien in Deutschland 1700-1800. Munich: C. H. Beck.

Christensson, Jakob. 1996. Lyckoriket: Studier i svensk Upplysning [Land of Bliss: A Cultural History of the Swedish Enlightenment]. Stockholm: Atlantis.

Clark, Peter. 2001. British Clubs and Societies, 1580-1800: the Origins of an Associational World. Oxford Studies in Social History. Oxford: Clarendon Press.

Colley, Linda. 1996. Britons: Forging the Nation, 1707-1837, 1st edn 1992. London: Vintage.

Damsholt, Tine. 2000. Fadrelandskarlighed og Borgerdyd. Patriotisk diskurs og militare reformer $i$ Danmark $i$ sidste del af 1700-tallet [Love of Country and Civic Virtue: Patriotic Discourse and Military Reforms in Denmark in the Last Part of the 18th Century]. Copenhagen: Museum Tusculanum.

Dülmen, Richard van. 1986. Die Gesellschaft der Aufklärer. Zur bürgerlicher Emanzipation und aufklärischen Kultur in Deutschland. Frankfurt a.Main: Fischer Verlag.

Elias, Norbert. 1997. Über den Prozess der Zivilisation. Soziogenetische und psychogenetische Untersuchungen, 1st edn 1939. Frankfurt am Main: Suhrkamp.

Engelhardt, J. 2007. 'Enlightenment in the provinces: the patriotic societies in the towns and country in the Danish state' in Sører Bitsch Christensen and Jørgen Mikkelsen (eds.), Urbanisation and Urban Culture in Denmark 1660-1848. Aarhus: Aarhus University Press.

Habermas, Jürgen. 1990. Strukturwandel der Öffentlichkeit. Untersuchungen zu einer Kategorie der bürgerlichen Gesellschaft, 1st edn 1962. Frankfurt am Main: Suhrkamp.

Herder, J. G. 1989. Ideen zur Philosophie der Geschichte der Menschheit, 1784-1791. Frankfurt am Main: Deutscher Klassiker Verlag.

Hobsbawn, E. J. 1990. Nations and Nationalism since 1780: Programme, Myth, Reality, 1st edn 1983. Cambridge: Cambridge University Press.

Hübner, Martin. 1772. Sørge-Tale over Greven af Bernstorff, fordum Stats-Minister og GeheimeRaad i Conseilet, samt det Kongl. Danske Landhuusholdnings-Selskabs første Prasident: holden $i$ 
Selskabets offentlige og høitidelige Møde den 12. Martii 1772 [Speech given to the Royal Society of Agriculture on 12 March 1772 upon the death of J. H. E. Bernstorff]. Copenhagen.

im Hof, Ulrich. 1982. Das gesellige Jahrhundert. Gesellschaft und Gesellschaften im Zeitalter der Aufklärung. Munich: C. H. Beck.

Lind, Gunner. 2005. 'Elites of the Danish composite state, 1460-1864: zones of fracture, mixing, and the struggle for hegemony', in Almut Bues (ed.), Zones of Fracture in Modern Europe: the Baltic Countries, the Balkans, and Northern Italy. Wiesbaden: Harrassowitz Verlag.

Löfgren, Orvar. 1989. 'The nationalization of culture', Ethnologia Europaea 19, 1: 5-24.

Malnes, Raino and Knut Midgaard. 1993. Politisk tenkning fra antikken til vår tid [Political Thought from Classical Antiquity to Present Day]. Oslo: Universitetsforlaget.

Müller, Hans-Heinrich. 1975. Akademie und Wirtschaft im 18. Jahrhundert. Agrarökonomische Preisaufgaben und Preisschriften der Preussischen Akademie der Wissenschaft (Versuch, Tendenzen und Überblick). Berlin: Akademische Verlag.

Prignitz, Cristoph. 1981. Vaterlandsliebe und Freiheit. Deutscher Patriotismus von 1750 bis 1850. Wiesbaden: Steiner Verlag.

Samuel, Raphael (ed.). 1989. Patriotism: the Making and Unmaking of British National Identity. London: Routledge.

Seligman, Adam B. 1995. The Idea of Civil Society. Princeton, NJ: Princeton University Press.

Selskabet for Borgerdyd [The Society for Civic Virtue]. 1785. Tale holdt den 9. Jan. 1785 [Speech delivered on 9 January 1785]. Copenhagen.

Smith, Anthony D. 1998. Nationalism and Modernism: a Critical Survey of Recent Theories of Nations and Nationalism. London: Routledge.

Storsveen, Odd Arvid. 1997. Norsk patriotisme før 1814 [Norwegian Patriotism before 1814]. Oslo: Norges Forskningsråd.

van Dülmen, Richard. 1986. Die Gesellschaft der Aufklärer. Zur bürgerliche Emanzipation und aufklärischen Kultur in Deustchland. Frankfurt am Main: Fischer Verlag.

Vierhaus, Rudolf (ed.). 1980. Deutsche patriotische und gemeinnützige Gesellschaften. Wolfenbütteler Forschungen, vol. 8. Munich: Kraus.

Viroli, Maurizio. 1997. For Love of Country: an Essay on Patriotism and Nationalism. Oxford: Oxford University Press.

Weber, Max. 1993. Die protestantische Ethik und der Geist des Kapitalismus, 1st edn 1905. Bodenheim: Athenäum Hain Hanstein.

Winge, Vibeke and Feldbæk. 1991. 'Tyskerfejden 1789-1790: Den første nationale konfrontation' [The German feud: the first national confrontation]. In Ole Feldbæk (ed.) Dansk Identitetshistorie [Danish Identity History], vol 2. Copenhagen: C. A. Reitzels Forlag. 